\title{
Hypolipidemic Effects of Irvingia gabonensis - Supplemented Diets in Male Albino Rats
}

\author{
Seun Elizabeth Kuyooro*1,2, Esther Omugha Abam ${ }^{1}$ and Elizabeth Bolaji Agbede ${ }^{1}$ \\ ${ }^{1}$ Biochemistry Unit, Department of Chemical Sciences, Bells University of Technology, P.M.B. 1015, Ota, Nigeria \\ ${ }^{2}$ Department of Biochemistry, Federal University of Agriculture, P.M.B.2240, Abeokuta, Nigeria
}

\begin{abstract}
Cardiovascular disease has become a disease of global concern. The present study investigated the effect of an Irvingia gabonensis - supplemented diet on cardiovascular disease risk. 24 male albino rats divided into 4 groups of 6 animals each were used. Diets containing varying amounts of Irvingia gabonensis seeds were prepared and fed to the rats for 4 weeks. Lipid profiles of the plasma total cholesterol, triacylglycerol, high-density liporotein (HDL) cholesterol and low density lipoprotein (LDL) cholesterol were determined. Generally, Irvingia gabonensis supplementation in diets resulted in reduced organ/body weight ratios. Total cholesterol, LDL-cholesterol levels and artherogenic indices were significantly reduced. The results of this study indicate that Irvingia gabonensis consumption has athero-protective potential as evidenced in the reduction in atherogenic indices in the rats. Results also suggest that the mechanism involved may be through reduction in cholesterol synthesis and transport to the peripheral tissues as observed in the decrease in LDL-cholesterol.
\end{abstract}

Keywords: Cardiovascular disease; Irvingia gabonensis; Total cholesterol; Atherogenic indices

\section{Introduction}

Atherosclerosis and its complications are a major cause of morbidity and mortality in both developed and developing nations. Atherosclerosis begins with damage to the artery caused by elevated levels of cholesterol and triacylglycerol in the blood, as well as high blood pressure. Aberrant regulation of lipid and lipoprotein homeostasis can lead to atherosclerosis [1-3].

Several clinical and epidemiological studies indicate a role for high-density lipoproteins (HDL) in protection against atherosclerosis and heart disease. Plasma levels of high-density lipoprotein (HDL) cholesterol are invariably found to be inversely associated with the risk of atherosclerosis [4-6]. Various pathways have been suggested to be involved in the molecular and physiological mechanisms by which HDL protects against atherosclerosis. Firstly, this protective effect has classically been ascribed to HDL-mediated reverse cholesterol transport (RCT), a multistep process which involves the removal of cholesterol from cells in peripheral tissues (e.g., macrophages and foam cells in the artery wall), and its delivery to the liver. HDL-associated cholesterol is converted to cholesteryl ester by lecithin cholesterol acyltransferase (LCAT) $[7,8]$. In addition, HDL is a carrier of antioxidant vitamins such as $\boldsymbol{\alpha}$-tocopherol (vitamin E), which helps to protect cells against the harmful effects of reactive oxygen species $[9,10]$. HDL is also associated with enzymes such as paraoxonase (PON) and platelet activating factor acylhydrolase (PAF-AH) that may play important roles in the removal of oxidized lipids from other lipoproteins such as low-density lipoprotein (LDL) [11-13]. HDL also triggers signaling events within cells leading to diverse consequences, including the activation of endothelial nitric oxide synthase (eNOS) and protection of cells in the vascular wall against apoptosis, processes which have been associated with protection against atherosclerosis [14-23].

Potential strategies including therapeutic and dietary approaches that increase the levels of HDL, augment its anti-atherogenic properties, and promote reverse cholesterol transport (RCT) are considered particularly desirable $[3,24]$. The relationship between dietary fats, and health and disease is one of the most active areas of biochemical, nutritional, and medical research. However the role of dietary fat in health and disease remains one of considerable controversy.
Studies on some African nuts have found them beneficial in lowering undesirable LDL-cholesterol and possessing athero-protective properties. Irvingia gabonensis is one of such plants. This fruit tree species from the Irvingicaea family is found naturally in the tropical forests of Angola, Nigeria, Congo, Uganda and Cote d'Ivoire, in Africa [25]. It is commonly grown in West African countries including Nigeria, Southern Cameroon, Ghana and Benin.

Irvingia gabonensis seed has nutritive, medicinal and industrial uses. It is rich in fat and protein. The seeds are richer in lipids than other oil seeds and legumes: soyabeans, rapeseed, cotton seed, groundnut and melon. The seeds act as source of human food and constitute important part of the diet in Nigeria. The seeds are ground and used as thickening agents in soups. Other parts of the tree, like the bark and the leaves have been used as purgatives and in gastrointestinal conditions and for sore and wound healing. The oil can be processed into soap, cosmetics or pharmaceuticals $[25,26]$.

Some earlier studies have shown the inhibitory effects of Irvingia gabonensis on erythrocyte membrane adenosine triphosphatase in diabetics. It has been shown that the seed and oil free seed powder has hypoglycemic effect and has been used for the treatment of type II diabetes [27-29]. The in vitro hepatoprotective effects of the crude extract of Irvingia gabonensis and some isolated metabolites have also been examined [30]. However, there is paucity of information on diet based dose - effect studies on Irvingia gabonensis. Therefore, this research was carried out to investigate the effects of various concentrations of Irvingia gabonensis - supplementation in the diet on lipid metabolism of male albino rats.

*Corresponding author: Elizabeth Bolaji Agbede, Biochemistry Unit, Department of Chemical Sciences, Bells University of Technology, P.M.B. 1015, Ota, Nigeria, E-mail: elizabethskuyooro@gmail.com

Received: March 10, 2017; Accepted: March 30, 2017; Published April 03, 2017

Citation: Kuyooro SE, Abam EO, Agbede EB (2017) Hypolipidemic Effects of Irvingia gabonensis - Supplemented Diets in Male Albino Rats. Biochem Anal Biochem 6: 316. doi: 10.4172/2161-1009.1000316

Copyright: (c) 2017 Kuyooro SE, et al. This is an open-access article distributed under the terms of the Creative Commons Attribution License, which permits unrestricted use, distribution, and reproduction in any medium, provided the original author and source are credited. 


\section{Materials and Methods}

\section{Chemicals}

Commercial Kits used for Cholesterol and Triacylglycerol determination were obtained from Randox Laboratories Limited, United Kingdom. All other chemicals used in this study were of the purest analytical grade available.

\section{Collection of the samples}

African Mango seeds were supplied by a recognised farm produce merchant, at Sango Market, East of Ogun State, Nigeria. The seeds were dried, ground and stored in a dry plastic container prior to analysis.

\section{Proximate composition}

Moisture, crude fat and dry matter content were determined according to the standard methods of Association of Official Analytical chemists, (A.O.A.C.,) [31]. Nitrogen was determined by the microkjeldahl method as described by Pearson [32] and the result was used for estimating crude protein content by multiplying by 6.25 . The ash content was determined using the method described by Pearson [32].

\section{Phytochemical composition}

Quantitative determinations of the following constituents were done. Alkaloids were estimated by methods of Harbourne [33], Anthocyanins by Sims and Gamon [34], Cardiac glycoside by Trease and Evans [35], Carotenoid by Sims and Gamon [34], Flavonoid by Bao et al. [36] and total phenolic content by Singleton et al. [37] and Tannins by Van Burden and Robinson [38].

\section{Experimental diets}

The experimental diets were prepared as described in Tables 1 and 2. The constituents were mixed together thoroughly to achieve homogeneity and pelletized. They were dried in the oven and stored at room temperature until needed.

\section{Experimental protocol}

Male albino rats weighing $100 \mathrm{~g}$ to $150 \mathrm{~g}$ were obtained from

\begin{tabular}{|c|c|}
\hline Component & Units $\mathbf{( g / k g )}$ \\
\hline Fish meal & $180 \mathrm{~g} / \mathrm{kg}$ \\
\hline Corn Starch & $570 \mathrm{~g} / \mathrm{kg}$ \\
\hline Oil & $200 \mathrm{~g} / \mathrm{kg}$ \\
\hline Salt and Vitamin mixture & $50 \mathrm{~g} / \mathrm{kg}$ \\
\hline
\end{tabular}

Table 1: Composition of basal (control) diet

\begin{tabular}{|c|c|}
\hline Diet (Control Diet) & Composition (Basal diet) \\
\hline Test Diet 1 & Basal diet and $13.7 \mathrm{mg}$ of $I . \mathrm{g}$. per day/ rat \\
\hline Test Diet 2 & Basal diet and $27.4 \mathrm{mg}$ of $I . \mathrm{g}$ per day/ rat \\
\hline Test Diet 3 & Basal diet and $54.8 \mathrm{mg}$ of $I . \mathrm{g}$ per day/ rat \\
\hline
\end{tabular}

Table 2: Summary of diets and their composition.
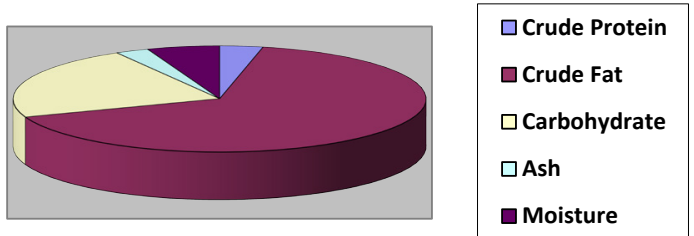

Figure 1: Proximate composition of Irvingia gabonensis seed

\begin{tabular}{|c|c|c|c|c|c|}
\hline Diet & $\begin{array}{c}\text { Crude } \\
\text { Protein } \\
\text { (g/100g) }\end{array}$ & $\begin{array}{c}\text { Crude } \\
\text { Fat } \\
\mathbf{( g / 1 0 0 g )}\end{array}$ & $\begin{array}{c}\text { Carbohydrate } \\
\text { content } \\
\mathbf{( g / 1 0 0 g )}\end{array}$ & $\begin{array}{c}\text { Ash } \\
\text { content } \\
\text { (g/100g) }\end{array}$ & $\begin{array}{c}\text { Moisture } \\
\text { content } \\
\text { (g/100g) }\end{array}$ \\
\hline $\begin{array}{c}\text { Control } \\
\text { Diet }\end{array}$ & 7.37 & 21.2 & 54.41 & 9.32 & 7.72 \\
\hline Test Diet 1 & 7.43 & 26 & 54.69 & 9.89 & 7.30 \\
\hline Test Diet 2 & 7.34 & 24 & 49.38 & 2.72 & 11.25 \\
\hline Test Diet 3 & 7.38 & 30 & 43.10 & 8.67 & 10.85 \\
\hline
\end{tabular}

Table 3: Proximate composition of diets.

the animal house of the Department of Biochemistry, University of Ibadan, Ibadan. They were kept in standard cages in the animal house, Department of Biochemistry, Bells University of Technology, Ota and given access to normal rat chow and clean water. They were acclimatized and maintained on a $12 \mathrm{hr}$ light-dark cycle for 14 days before the start of the experiment and the quantity of feed consumed was measured per cage. The animals were then assigned into 4 groups of 6 animals each and were fed the control and test diets for 28 days with water ad libitum. Body weights of animals were measured weekly with an electronic scale and food consumption monitored throughout the experimental period. Thereafter, the rats were sacrificed and plasma and lipoproteins of the rats were assessed for cholesterol and triglyceride analyses.

\section{Biochemical analyses}

Plasma and lipoprotein lipid profiles: Plasma concentrations of total cholesterol and triacylglycerol were determined with commercial kits (Randox Laboratories Limited, United Kingdom). High density lipoprotein (HDL) cholesterol and triacylglycerol were determined in plasma with same commercial kits for total cholesterol and triacylglycerol after very low density lipoproteins (VLDL) and Low density lipoprotein (LDL) were precipitated by addition of phosphotungstic acid in the presence of magnesium ions using commercial kit (Randox Laboratories Limited, United Kingdom). LDL cholesterol values were extrapolated according to the methods of Friedewald et al. [39].

Lipid peroxidation assay and protein level estimation: Protein concentration of plasma was estimated by Biuret method [40] which involves the addition of potassium iodide to prevent precipitation of copper ions. Briefly, $0.5 \mathrm{ml}$ of sample was pipette into a test tube and 4.5 $\mathrm{ml}$ of Biuret reagent was added to the sample and allowed to stand for 30 minutes. The absorbance was then measured against reference blank at $545 \mathrm{~nm}$ using spectrophotometer. Lipid peroxidation in plasma was estimated by measuring thiobarbituric acid reactive substances produced during lipid peroxidation as described by Varshey and Kale [41]. Briefly, $0.2 \mathrm{ml}$ of sample was added to $0.8 \mathrm{ml}$ of phosphate buffer and $0.5 \mathrm{ml}$ of $10 \%$ trichloroacetic acid was added. $0.5 \mathrm{ml}$ of $0.75 \%$ thiobarbituric acid was added and placed in water bath for 45 minutes at $80^{\circ} \mathrm{C}$, cooled in ice and centrifuged at room temperature for 10 minutes at $3000 \mathrm{rpm}$. The absorbance of the clear supernatant was measured against reference blank at $532 \mathrm{~nm}$ using spectrophotometer.

\section{Statistical analysis}

Data are expressed as mean \pm S.E.M. One way analysis of variance (ANOVA) followed by Duncan Multiple Comparisons was used to analyse the results with $\mathrm{p}<0.05$ considered significant.

\section{Results}

Table 1 shows the composition of the control diet. The summary of the control and test diets is shown in Table 2. The result of proximate analysis of the test seed is depicted in Figure 1. The seed contained crude protein-3.39\%, fat- $66 \%$, carbohydrate- $22.28 \%$, ash $-2.63 \%$ and moisture content-5.7\%. Table 3 depicts the results of proximate composition of 
the diets. The addition of increasing amount of the seed into diet caused an increase in the fat content of the test diets compared with the control diet. The results of phytochemical analysis of the seed is shown in Table 4.

The effect of the seed on organ/body weight ratios of rats is presented in Table 5. There was significant decrease $(p<0.05)$ in kidney weight to body weight ratio in all test groups compared with the control. The ratio for other organs isolated did not vary much compared to the control although there was a general trend of decrease in the ratio in all the test groups compared with control.

Table 6 depicts the effect of the test diets on lipid profiles. A significant decrease $(p<0.05)$ in the levels of Total Cholesterol and LDLCholesterol in all test groups was observed compared with the control. The plasma Total Cholesterol cencentration was reduced by $47.76 \%$, $35.32 \%$ and $43.16 \%(\mathrm{p}<0.05)$ and LDL- Cholesterol concentration by $80.51 \%, 64.90 \%$ and $66.06 \%(\mathrm{p}<0.05)$ in test group 1,2 and 3 respectively compared with the control. There was no significant difference $(\mathrm{p}<0.05)$ in triacylglycerol levels. A decrease in triacylglycerol levels was seen in test groups 3 and 4 compared with the control. There was no significant difference $(\mathrm{p}<0.05)$ in HDL- cholesterol and HDL- triacylglycerol levels in all test groups compared with the control. There was significant reduction $(\mathrm{p}<0.05)$ in the artherogenic indices in all test groups compared with control as shown in Table 7. The Total Cholesterol/ HDL-Cholesterol ratio was also reduced by $48.24 \%, 47.35 \%, 39.12 \%$ $(\mathrm{p}<0.05)$ and LDL-Cholesterol/ HDL-Cholesterol ratio by $80.09 \%$, $71.76 \%$ and $62.96 \%(p<0.05)$ in test group 1,2 and 3 respectively.

The effect of Irvingia gabonensis seed on plasma total protein and malondialdehyde levels is depicted in Table 8 . There was significant difference $(\mathrm{p}<0.05)$ in plasma total protein levels in the test groups

\begin{tabular}{|c|c|}
\hline Phytochemicals & Quantity $\mathbf{( m g / 1 0 0 ~} \mathbf{~ g )}$ \\
\hline Alkaloid & $78.09 \pm 0.44$ \\
\hline Anthocyanin & $20.41 \pm 0.04$ \\
\hline Cardiac Glycoside & $40.42 \pm 0.49$ \\
\hline Carotenoid & $1.72 \pm 0.02$ \\
\hline Flavonoid & $21.16 \pm 0.18$ \\
\hline Phenol & $53.03 \pm 0.29$ \\
\hline Tannin & $22.58 \pm 0.26$ \\
\hline Values are mean \pm Standard Error of Means (S.E.M.). \\
\hline
\end{tabular}

Table 4: Phytochemical composition of Irvingia gabonensis.

\begin{tabular}{|c|c|c|c|c|}
\hline Groups & LW/BW & KW/BW & SW/BW & HW/BW \\
\hline 1 & $0.038 \pm 0.002^{\mathrm{a}}$ & $0.011 \pm 0.004^{\mathrm{a}}$ & $0.005 \pm 0.001^{\mathrm{a}}$ & $0.004 \pm 0.000^{\mathrm{a}}$ \\
\hline 2 & $0.037 \pm 0.002^{\mathrm{a}}$ & $0.006 \pm 0.000^{\mathrm{a}, \mathrm{b}}$ & $0.003 \pm 0.000^{\mathrm{a}}$ & $0.004 \pm 0.000^{\mathrm{a}}$ \\
\hline 3 & $0.036 \pm 0.003^{\mathrm{a}}$ & $0.003 \pm 0.000^{\mathrm{a}}$ & $0.003 \pm 0.000^{\mathrm{a}}$ & $0.004 \pm 0.000^{\mathrm{a}}$ \\
\hline 4 & $0.033 \pm 0.002^{\mathrm{a}}$ & $0.007 \pm 0.000^{\mathrm{a}, \mathrm{b}}$ & $0.003 \pm 0.000^{\mathrm{a}}$ & $0.003 \pm 0.000^{\mathrm{a}}$ \\
\hline
\end{tabular}

Values are mean \pm Standard Error of Means (S.E.M.).

Values in a column with different superscripts are significantly different from each other at $p<0.05$

Abbreviations: LW: Liver Weight; SW: Spleen Weight; BW: Body Weight; KW: Kidney Weight; HW: Heart Weight

Table 5: Effect of diets on organ/ body weight ratio of rats. compared with the control. A decrease in malondialdehyde levels was observed in the test groups compared with the control.

\section{Discussion}

\section{Proximate and phytochemical composition}

In the recent years, there have been increased considerations on the use of vegetable oils in various industries because the oils have high flash points, very high viscosity index, they are biodegradable and nontoxic to the environment [42]. These valuabe properties of oils from oil-bearing seeds have increased interest in their use as lubricant. The oil from Irvingia gabonensis kernel has been evaluated as a lubricant on the basis of its effect on the flow rate of granules, disintegration time and dissolution rate of tablets [43].

From previous findings, the crude fat content of $I$. gabonensis kernels and seeds ranged between $37.5 \%$ to $75.5 \%$ [44,45]. The high fat content of Irvingia gabonensis, (66\%) seed observed in this study therefore supports these reports and shows that the seed is a good source of vegetable oil which could serve as potential lubricant over the conventional ones used for tablet formulations. The phytochemical composition showed that alkaloid and carotenoid are the most and least abundant bioactive compounds respectively, in the test seed. The observed reduction in total cholesterol and LDL cholesterol levels could be as a result of the presence of these phytochemicals.

\section{The effect of I. gabonensis on organ/body weight ratio}

In toxicological experiments, comparison of organ weight between treated and untreated groups of animals have conventionally been used to evaluate the toxic effects of the test article [46,47]. Reasons for the usefulness of weighing organs, especially liver and kidney, include their sensitivity to predict toxicity, enzyme induction, lipidosis, physiologic pertubations and metabolism; they correlates well with histopathological changes, there are little interanimal variability and there is available historical range data. Organ to body weight ratio is helpful in normalizing the variability due to nutritional status and in studies with anti-obesity compounds $[48,49]$. The results of this study showed that the seed had profound effect of weight reduction on the kidney than other organs isolated. This could be due to the higher sensitivity of the organ. In addition, the general trend of reduction of the organ weight to body weight ratio in the test groups is an indication that Irvingia gabonensis seed has less or no toxic effect on the organs.

\section{The effect of I. gabonensis on lipid profile}

Like other soluble fibers, I. gabonensis seed fibre can bind to bile acids in the gut and carry them out of the body in the faeces, which requires the body to convert more cholesterol into bile acids [50,51]. This can result in the lowering of blood cholesterol as well as other blood lipids. High-fibre diet has been shown to cause reduction of plasma total cholesterol by $6.7 \%$, triacylglycerols by $10.2 \%$ and VLDL cholesterol by $12.5 \%$, plasma LDL cholesterol by $6.3 \%$ lowered and no change in HDL cholesterol [52]. Also, I. gabonensis seeds have been

\begin{tabular}{|c|c|c|c|c|c|}
\hline Groups & Total Cholesterol & Triacylglycerol & HDL- Cholesterol & HDL- Triacylglycerol & LDL- Cholesterol \\
\hline 1 & $119.13 \pm 13.53^{\mathrm{a}}$ & $44.62 \pm 4.80^{\mathrm{a}}$ & $36.44 \pm 3.08^{\mathrm{a}}$ & $140.43 \pm 5.58^{\mathrm{a}}$ & $13.77 \pm 14.46^{\mathrm{a}}$ \\
\hline 2 & $62.23 \pm 6.82^{\mathrm{b}}$ & $59.08 \pm 2.39^{\mathrm{b}}$ & $36.03 \pm 3.85^{\mathrm{a}}$ & $118.65 \pm 12.04^{\mathrm{a}}$ \\
\hline 3 & $77.05 \pm 7.49^{\mathrm{b}}$ & $38.82 \pm 4.37^{\mathrm{a}}$ & $43.40 \pm 3.27^{\mathrm{a}}$ & $14.38 \pm 6.68^{\mathrm{b}}$ \\
\hline 4 & $67.71 \pm 4.91^{\mathrm{b}}$ & $43.90 \pm 4.23^{\mathrm{a}}$ & $33.90 \pm 3.23^{\mathrm{a}}$ & $25.89 \pm 6.59^{\mathrm{b}}$ \\
\hline
\end{tabular}




\begin{tabular}{|c|c|c|}
\hline Group & T Chol / HDL-Chol & LDL- Chol / HDL - Chol \\
\hline 1 & $3.40 \pm 0.57^{\mathrm{a}}$ & $2.16 \pm 0.59^{\mathrm{a}}$ \\
\hline 2 & $1.76 \pm 0.19^{\mathrm{b}}$ & $0.43 \pm 0.18^{\mathrm{b}}$ \\
\hline 3 & $1.79 \pm 0.16^{\mathrm{b}}$ & $0.61 \pm 0.15^{\mathrm{b}}$ \\
\hline 4 & $2.07 \pm 0.27^{\mathrm{b}}$ & $0.80 \pm 0.26^{\mathrm{b}}$ \\
\hline
\end{tabular}

Values are Mean \pm Standard Error of Means (S.E.M.).

Values in a column with different superscripts are significantly different from each other at $\mathrm{p}<0.05$.

Table 7: Effect of diets on artherogenic indices.

\begin{tabular}{|c|c|c|}
\hline Group & Total Protein $(\mathbf{m g} / \mathbf{m l})$ & MDA Equivalents (units/mg protein) \\
\hline 1 & $0.77 \pm 0.01^{\mathrm{a}}$ & $1.08 \pm 0.01^{\mathrm{a}}$ \\
\hline 2 & $0.81 \pm 0.02^{\mathrm{a}, \mathrm{b}}$ & $1.06 \pm 0.02^{\mathrm{a}}$ \\
\hline 3 & $0.81 \pm 0.01^{\mathrm{a}, \mathrm{b}}$ & $1.05 \pm 0.02^{\mathrm{a}}$ \\
\hline 4 & $0.82 \pm 0.01^{\mathrm{b}}$ & $1.00 \pm 0.02^{\mathrm{b}}$ \\
\hline
\end{tabular}

Values are Mean \pm Standard Error of Means (S.E.M.)

Values in a column with different superscripts are significantly different from each other at $p<0.05$.

Table 8: Effect of diets on plasma total protein and malondialdehyde equivalents (MDA) levels.

shown to significantly decrease total cholesterol, LDL-cholesterol, triacylglycerols, and to increase HDL-cholesterol in obese humans [53]. The findings of this study are in agreement - ie a significant decrease in total cholesterol and LDL cholesterol but no significant change in HDL cholesterol and Triacylglycerols.

The evident significant reduction in total cholesterol levels observed in all test diets could be attributed to the enhanced excretion of cholesterol and its catabolism to bile salts due to the presence of unsaturated fatty acids found abundantly in oils from plant sources. The following mechanism explains the observed reduction in LDL- cholesterol levels. In the endoplasmic reticulum, intracellular cholesterol is sensed by the protein, sterol regulatory element-binding protein 1 and 2 (SREBP). In the presence of cholesterol, SREBP is bound to two other proteins: SREBP-cleavage-activating protein (SCAP) and Insig-1. When cholesterol levels fall, Insig-1 dissociates from the SREBP-SCAP complex, allowing the complex to migrate to the Golgi apparatus, where SREBP is cleaved by S1P and S2P (site- 1 and -2 protease), two enzymes that are activated by SCAP when cholesterol levels are low. The cleaved SREBP then migrates to the nucleus and acts as a transcription factor to bind to the sterol regulatory element (SRE), which stimulates the transcription of many genes incuding the lowdensity lipoprotein (LDL) receptor which scavenges circulating LDL from the bloodstream $[54,55]$. Artherogenic indices have been used to know the predisposition to artherosclerosis and other related diseases. The higher the artherogenic index, the higher the risk of having the disease. In this study, the consumption of Irvingia gabonensis caused significant reduction of artherogenic risk in all the test groups.

\section{Effect of I. gabonensis on lipid peroxidation}

The degree of lipid peroxidation was measured in terms of malondialdehyde (MDA) oncentration in the plasma. MDA is an end product of lipid peroxidation and a marker of oxidative stress. The consumption of I. gabonensis at the various concentration studied in the diets of the rats caused a non-significant decrease in plasma MDA levels. Thus implying that the diets were safe for consumption and were not toxic to the rats. This finding is similar to a recent study which showed that $I$. Wombolu, a close specie to the test seed reduced the level of MDA in diabetic rats [56]. The observed decrease in MDA levels could be due to the presence of potent phytochemicals especially in $I$. gabonensis seeds.

\section{Conclusion}

This study has shown that I. gabonensis seed has hypolipidemic effects in rats. Diet is of great importance in the incidence of cancer, atherosclerosis and a number of other related pathological diseases. The quantities of $I$. Gabonensis incorporated into the diets of the rats were to simulate varying degrees of adult human consumption. Therefore $I$. Gabonensis consumption may be a useful intervention in the prevention of atherosclerosis due its athero-protective properties.

\section{References}

1. Stary HC (2000) Natural history and histological classification of atherosclerotic lesions. Arterioscler. Thromb Vasc Biol 20: 1177-1178.

2. Lusis AJ (2000) Review article Atherosclerosis. Nature 407: 233-241.

3. Meyers CD, Kashyap ML (2004) Pharmacologic elevation of high-density lipoproteins: Recent insights on mechanism of action and atherosclerosis protection. Curr Opin Cardiol 19: 366-373.

4. Kwiterovich PO Jr (1998) The anti-atherogenic role of high-density lipoprotein cholesterol. Am J Cardiol 82: 13-21.

5. Nicholls SJ, Rye KA, Barter PJ (2005) High-density lipoproteins as therapeutic targets. Curr Opin Lipidol 16: 345-349.

6. Castelli WP (1988) Cholesterol and lipids in the risk of coronary artery diseasethe Framingham Heart Study. Can J Cardiol 4: 5-10.

7. Breslow J (1995) Familial disorders of high density lipoprotein metabolism. In Scriver CR, Beaudet AL, Sly WS, Valle D (Eds), The metabolic and molecular bases of inherited diseases. McGraw-Hill, New York, 2031-2052.

8. Ng DS (2004) Insight into the role of LCAT from mouse models. Rev Endocr Metab Disord 5: 311-318.

9. Herrera E, Barbas C (2001) Vitamin E: action, metabolism and perspectives. J Physiol Biochem 57: 43-56.

10. Mardones P, Strobel P, Miranda S, Leighton F, Quinones V, et al. (2002) Alphatocopherol metabolism is abnormal in scavenger receptor class B type I (SRBI)-deficient mice. J Nutr 132: 443-449.

11. Tselepis AD, Chapman MJ (2002) Inflammation, bioactive lipids and atherosclerosis: Potential roles of a lipoprotein-associated phospholipase A2, platelet activating factor-acetylhydrolase. Atherosclerosis 3: 57-68.

12. Mackness MI, Durrington PN, Mackness B (2004) The role of paraoxonase 1 activity in cardiovascular disease: Potential for therapeutic intervention. Am J Cardiovasc. Drugs 4: 211-217.

13. Connelly PW, Draganov D, Maguire GF (2005) Paraoxonase-1 does not reduce or modify oxidation of phospholipids by peroxynitrite. Free Radic Biol Med 38: 164-174.

14. Mineo C, Shaul PW (2003) HDL stimulation of endothelial nitric oxide synthase: a novel mechanism of HDL action. Trends Cardiovasc Med 13: 226-231.

15. Mineo C, Yuhanna IS, Quon MJ, Shaul PW (2003) High density lipoproteininduced endothelial nitric-oxide synthase activation is mediated by Akt and MAP kinases. J Biol Chem 278: 9142-9149.

16. Gong M, Wilson M, Kelly T, Su W, Dressman J, et al. (2003) HDL-associated estradiol stimulates endothelial NO synthase and vasodilation in an SR-BIdependent manner. J Clin Invest 111: 1579-1587.

17. Li XA, Titlow WB, Jackson BA, Giltiay N, Nikolova-Karakashian M (2002) High density lipoprotein binding to scavenger receptor, class $B$, type I activates endothelial nitric-oxide synthase in a ceramidedependent manner. J Biol Chem 277: 11058-11063.

18. Uittenbogaard A, Shaul PW, Yuhanna IS, Blair A, Smart EJ (2000) High density lipoprotein prevents oxidized low density lipoprotein-induced inhibition of endothelial nitric-oxide synthase localization and activation in caveolae. J Biol Chem 275: 11278-11283.

19. Yuhanna IS, Zhu Y, Cox BE, Hahner LD, Osborne-Lawrence S, et al. (2001) High-density lipoprotein binding to scavenger receptor-BI activates endothelial nitric oxide synthase. Nat Med 7: 853-857.

20. Nofer JR, Junker R, Pulawski E, Fobker M, Levkau B, et al. (2001) High density lipoproteins induce cell cycle entry in vascular smooth muscle cells via mitogen activated protein kinasedependent pathway. Thromb Haemost 85: 730-735. 
Citation: Kuyooro SE, Abam EO, Agbede EB (2017) Hypolipidemic Effects of Irvingia gabonensis - Supplemented Diets in Male Albino Rats. Biochem Anal Biochem 6: 316. doi: 10.4172/2161-1009.1000316

Page 5 of 5

21. Nofer JR, Levkau B, Wolinska I, Junker R, Fobker M, et al. (2001) Suppression of endothelial cell apoptosis by high density lipoproteins (HDL) and HDLassociated lysosphingolipids. J Biol Chem 276: 34480-34485

22. Nofer JR, Van der Giet M, Tolle M, Wolinska I, Lipinski KVW, et al. (2004) HDL induces NO-dependent vasorelaxation via the lysophospholipid receptor S1P3. J Clin Invest 113: 569-581.

23. Li XA, Guo L, Dressman JL, Asmis R, Smart EJ (2005) A novel ligandindependent apoptotic pathway induced by scavenger receptor class $B$ type I and suppressed by endothelial nitric-oxide synthase and high density lipoprotein. J Biol Chem 280: 19087-19096.

24. Toth PP, Davidson MH (2004) Therapeutic interventions targeted at the augmentationof reverse cholesterol transport. Curr Opin Cardiol 19: 374-379.

25. Lost Crops of Africa, Volume II, vegetables (2006) The National Academy of Sciences, Washington 119-135.

26. Abulude FO, Alo FI, Ashafa SL, Fesobi M (2008) Vegetables. Continental J. Food Science and Technology 2: 33-36.

27. Adamson I, Okafor C, Abu-Bakare A (1986) Erythrocyte membrane ATPases in diabetes: Effect of Dikanut (Irvingia gabonensis). Enzyme 36: 212-215.

28. Adamson I, Okafor C, Abu-Bakare A (1990) A supplement of Dikanut (Irvingia gabonensis) improves treatment of type II diabetics. West Afric J Med 9: 108115

29. Hossain MS, Sokeng S, Shoeb M, Hasan K, Mosihuzzaman M, et al. (2012) Hypoglycemic effect of Irvingia gabonensis (Aubry-Lacomate Ex. Ororke), Baill in Type 2 Diabetic Long-Evans Rats Dhaka. Univ J Pharm Sci 11: 19-24.

30. Donfack JH, Fotso GW, Ngameni B, Tsofack FN, Tchoukoua A, et al. (2010) In vitro hepatoprotective and antioxidant activities of the crude extract and isolated compounds from Irvingia gabonensis. As J Trad Med 5: 3.

31. AOAC (1990) Official Methods of Analysis. Association of Official Analytical Chemists. Washington, D.C

32. Pearson D (1976) Chemical analysis of foods. Churchill Living stone, London.

33. Harborne JB (1973) Phytochemical methods. Chapman and Hall, London 49188

34. Sims DA, Gamon JA (2002) Relationship between leaf pigment content and spectral reflectance across a wide range of species, leaf structures and developmental stages. Remote Sensing of Environment 81: 337-354

35. Trease GE, Evans WC (1989) Pharmacognsy, Macmillian publishers, Brailliar Tiridel Canada, 290.

36. Bao J, Cai Y, Sun M, Wang G, Corke H (2005) Anthocyanins, flavonols and free radical scavenging activity of Chinese bayberry (Myrica rubra) extracts and their color properties and stability. J Agric Food Chem 53: 2327-2332

37. Singleton VL, Orthofer R, Lamuela-Raventòs RM (1999) Analysis of total phenols and other oxidation substrates and other oxidation substrates and antioxidants by means of Folin-Ciocalteu reagent. Methods in Enzymology 299: 152-178.

38. Van Buren JP, Robinson WB (1981) Formation of complexes between protein and tannic acid. J Agric Food Chem 17: 772-777.
39. Friedewald WT, Levy RI, Fredrickson DS (1972) Estimation of the concentration of low-density lipoprotein cholesterol in plasma, without use of the preparative ultracentrifuge. Clin Chem 18: 499-502.

40. Gornal AG, Bardwil G, David MM (1949) Determination of serum proteins by mean of Biuret reactions. Biochem 177: 751-756.

41. Varshney R, Kale RK (1990) Effects of calmodulin antagonists on radiationinduced lipid peroxidation in microsomes. Int J Radiat Biol 58: 733-743.

42. Udeala OK, Onyechi JO, Agu SI (2011) Preliminary evaluation of dika fat, a new tablet lubricant. J Pharm Pharmacol 32: 6-9.

43. Abidakun OA, Koya OA (2013) Dika nut oil as base oil for lubricants: effect of processing conditions on physicochemical properties. Lubr Sci 25: 29-38.

44. Ejiofor MAN (1994) National Values of Ogbono (Irvingia gabonensis, Va excelsa). International Center for Research on Agroforestry and International Institute of Tropical Agriculture Conference on Irvingia gabonansis Ibadan, Nigeria.

45. Leakey RRB, Tchoundjeu Z, Schreckenberg K, Shackleton S, Shackleton C (2005) Agroforestry Tree Products (ATFTPs): Targeting poverty reduction and enhancing livelihoods. Int J Agric Sust 3: 1-23.

46. Peters JM, Boyd EM (1966) Organ weight and water levels of the rats following reduced food intake. J Nutr 90: 354-360.

47. Pfeiffer CJ (1968) A mathematical evaluation of the thymic weight parameter Toxicol Appl Pharmacol 13: 220-227.

48. Roy D, Andrews PA (2004) Non-clinical testing from theory to practice. In: Anticancer drug development guide. Humana Press, Totowa, New Jersey, USA

49. Michael B, Yano B, Sellers RS, Perry R, Morton D, et al. (2007) Evaluation of organ weight for rodent and non-rodent toxicity studies: A review of regulatory guidelines and a survey of current practices. Toxicol. Pathol 35: 742-750.

50. Arvill A, Bodin L (1995) Effect of short-term ingestion of konjac glucomannan on serum cholesterol in healthy men. Am J Clin Nutr 61: 585-589.

51. Vido L, Facchin P, Antonello I (1993) Childhood obesity treatment: Double blinded trial on dietary fibres (glucomannan) versus placebo. Padiatr Padol 28 133-136.

52. Walsh DE, Yaghoubian V, Behforooz A (1984) Effect of glucomannan on obese patients: A clinical study. Int J Obes 8: 289-293.

53. Ngondi JL, Oben EJ, Minka SR (2005) The effect of Irvingia gabonensis seeds on body weight and blood lipids of obese subjects in Cameroon. Lipids Health Dis $4: 12$

54. Brown MS, Goldstein JL (1997) The SREBP Pathway: Regulation of cholestero metabolism by proteolysis of a membrane bound transcription factor. Cell 89 : 331-340.

55. Horton JD, Goldstein JL, Brown MS (2002) SREBPs: Activators of the complete program of cholesterol and fatty acid synthesis in the liver. J Clin Invest 109: 1125-1131.

56. Matsinkou RS, Ngondi JL, Kuate D, Mbofung C, Oben JE (2012) Antioxidant and anti-hyperglycemic potential of pulp extracts of Irvingia wombolu fruits. Biol Med 4: 10-19. 